\title{
PENGARUH PENGGUNAAN MEDIA PEMBELAJARAN TRAINER CONTROL MOTOR TERHADAP HASIL BELAJAR \\ INSTALASI MOTOR LISTRIK
}

${ }^{1}$ Nobby Sail Andi Supu, ${ }^{2}$ Irzan Zakir, ${ }^{3}$ Imam Arif Rahardjo

${ }^{1,2,3}$ PendidikanTeknik Elektro, Fakultas Teknik, Universitas Negeri Jakarta

Email : nobbysas12@gmail.com

\begin{abstract}
The research is intended to investigate the effect of learning media Trainer Control Motor to students' learning outcomes in installation of electric motor subject. The research used quantitative research with quasy experimental method. This research used two groups to be investigated, which are experimental group that was given the Trainer Control Motor for learning media and the other group that wasn't given the Trainer Control Motor learning media. The data collection process was done by giving the two groups post test. The collected data was processed by using $t$-test after it met the standard requirements and was homo-gen.

The finding shows that the value tcount > ttable that is 8,225 > 2,001 with 0,05 significant level. Accordingly, $H_{o}$ was rejected and $H_{i}$ is accepted which means there is a difference between experimental class' learning outcomes post-test and controlled class' learning outcomes post test. Based on the t-test measurement and improvement of learning outcomes, it can be concluded that there is an effect of Trainer Control Motor media learning to the students' learning outcomes in installation of electric motor subject.
\end{abstract}

Keywords: Learning Media, Learning Outcomes, Effect of learning media

\begin{abstract}
Abstrak
Penelitian ini bertujuan untuk mengetahui pengaruh media pembelajaran Trainer Control Motor terhadap hasil belajar. Jenis penelitian yang digunakan adalah penelitian kuantitatif, dengan metode quasy eksperimental. Pada penelitian digunakan dua kelompok yang akan diteliti, yakni kelompok eksperimen yang diberi perlakuan dengan diberikan media pembelajaran dengan Trainer Control Motor dan kelompok satu lagi diberi perlakuan dengan tidak memberian media pembelajaranTrainer Control Motor. Proses pengumpulan data dilakukan dengan post-test pada kedua kelas. Data yang telah terkumpul akan diolah dengan uji-t setelah data memenuhi persyaratan normal dan homogen.

Hasil penelitian menunjukkan bahwa $t_{\text {hitung }}>\mathrm{t}_{\text {tabel, }}$, yakni 8,225>2,001 dengan signifikansi 5\%. Maka $\mathrm{H}_{\mathrm{o}}$ ditolak dan $\mathrm{H}_{\mathrm{i}}$ diterima yang artinya terdapat perbedaan antara hasil belajar post-test kelas eksperimen dengan hasil belajar post-test kelas kontrol. Berdasarkan hasil perhitungan uji-t, maka dapat disimpulkan bahwa terdapat pengaruh media pembelajaran Trainer Control Motor terhadap hasil belajar instalasi motor listrik.
\end{abstract}

Katakunci: Media Pembelajaran, Hasil Belajar, Pengaruh media pembelajaran

\section{PENDAHULUAN}

Sekolah Menengah Kejuruan (SMK) merupakan lembaga pendidikan tingkat menengah yang bertanggung jawab dalam mencetak sumber daya manusia yang memiliki kemampuan akademis. Selain itu, SMK merupakan jenis pendidikan menegah yang secara khusus mempersiapkan lulusannya untuk menjadi tenaga kerja yang terampil serta kompetitif di DU/DI. Menurut Peraturan Pemerintah (PP) Republik Indonesia No. 19 Tahun 2005 Pasal 26 ayat 3 tujuan dari SMK yaitu: untuk meningkatkan kecerdasan, pengetahuan, kepribadian, akhlak mulia, serta keterampilan untuk hidup mandiri dan mengikuti pendidikan lebih lanjut sesuai dengan kejuruannya.

Instalasi Motor listrik merupakan salah satu mata pelajaran dalam pendidikan SMK. Dalam mata pelajaran ini peserta didik mempelajari beberapa hal seperti, mempelajari jenis - jenis motor listrik, pemanfaatan motor listrik, rangkaian utama motor listrik, dan rangkaian kendali motor listrik. Mengingat pentingnya peranan mata pelajaran, maka sudah seharusnya guru dan semua pihak yang terlibat dalam pembelajaran perlu memperhatikan strategi pembelajaran yang tepat dalam proses belajar mengajar agar peserta didik dapat menguasai standar kompetensi inti dan kompetensi dasar instalasi motor listrik, baik melalui pembelajaran pengetahuan seperti teori maupun pembelajaran keterampilan yaitu praktik.

Mayoritas lembaga pendidikan formal masih belum menerapkan media pembelajaran praktik yang dibutuhkan oleh peserta didik. Dalam Program Keahlian yang bersifat praktikum, penggunaan alat bantu berupa media 
pembelajaran memiliki pengaruh yang signifikankan bagi siswa dalam memahami secara mendalam materi yang diajarkan (Santoso, 2015).Untuk itu dengan adanya media pembelajaran diharapkan dapat membantu guru dalam penyampaian materi sekaligus memberikan variasi belajar bagi peserta didik. Hal ini sejalan dengan yang dikatakan (Rasimin, Subqi, Sapruto, \& Musyahadah, 2012) "Bahwa kehadiran media pembelajaran dapat membantu meningkatkan pemahaman peserta didik, penyajian data atau informasi yang lebih menarik dan terpercaya, memudahkan penafsiran data, dan memadatkan informasi. Pada dasarnya media pembelajaran mempunyai peran stategis dalam mensikapi proses belajar dan mengajar".

Dalam penelitian Putra (2014) membuktikan bahwa "Terdapat pengaruh penggunaan media pembelajaran trainer terhadap hasil praktik siswa kelas eksperimen yang menggunakan media pembelajaran trainer lebih tinggi dan terdapat perbedaan yang signifikan bila dibandingkan dengan kelas kontrol yang tidak menggunakan trainer pada mata pelajaran sistem kendali elektronik di Jurusan Teknik Ketenagalistrikan SMK. Hal ini menunjukkan media pembelajaran trainer sangat berpengaruh terhadap hasil belajar siswa.

Trainer Control Motor didesain dan dikembangkan sesuai dengan konsep dan layak sebagai media pembelajaran baik dari segi teknis, fungsi dan cara kerja dalam penggunaan sehingga diharapkan mampu meningkatkan hasil belajar mata pelajaran Instalasi Motor Listrik. Media pembelajaran praktik berupa Trainer Control Motor merupakan salah satu potensi yang dapat digunakan siswa SMK dalam mengenal lebih dalam perkembangan teknologi Instalasi yang ada di Industri, khususnya terkait mata pelajaran Instalasi Motor Listrik dalam program keahlian Teknik Instalasi dan Pemanfaatan Tenaga Listrik di SMKN 26 Jakarta.

Berdasarkan pemaparan latar belakang di atas, peneliti bermaksud untuk meneliti apakah terdapat pengaruh penggunaan media Trainer Control Motor terhadap hasil belajar instalasi motor listrik.

\section{METODE}

Tujuan dari penelitian ini adalah untuk mengetahui pengaruh penggunaan media pembelajaran Trainer Control Motor terhadap hasil belajar instalasi motor listrik. Subjek penelitian adalah siswa kelas XI jurusan Teknik Instalasi Tenaga Listrik di SMKN 26 Jakarta.

Populasi pada penelitian ini yaitu seluruh siswa Kelas XI Jurusan kelistrikan SMK Negeri 26 Jakarta. Pada penelitian yang dilakukan, teknik sampling yang diambil adalah simple random sampling. Simple random sampling digunakan untuk menentukan kelas mana yang akan dijadikan sebagai kelas eksperimen dan kelas mana yang akan dijadikan sebagai kelas kontrol adalah. Cara yang dilakukan adalah dengan membuat undian pada kertas. Pertama, peneliti menuliskan nama masing-masing kelas pada dua buah kertas kosong. Kemudian, peneliti melipat kertas dan mengocok kertas yang telah dilipat. Kertas pertama yang keluar dijadikan sebagai kelas eksperimen dan kelas yang tidak keluar dalam kocokan akan dijadikan sebagai kelas kontrol. Setelah dilakukan pengocokan, didapatkan XI TIPTL 1 sebagai kelas eksperimen dan kelas XI TIPTL 2 sebagai kelas kontrol.

Pada penelitian, uji validitas menggunakan rumus korelasi product moment dengan angka kasar, sedangkan untuk uji reliabilitas digunakan rumus Spearman-Brown. Selanjutnya, uji prasyarat analisis digunakan uji lilifors untuk melihat normalitas dan uji fisher untuk melihat homogenitas. Dalam penelitian, untuk menguji hipotesis digunakan uji-t dengan taraf kesalahan 5\%.

\section{HASIL DAN PEMBAHASAN}

\section{Hasil Belajar Post-Test Instalasi Motor Listrik Kelas Kontrol}

Berdasarkan hasil post-test, pada kelas kontrol di didapatkan perolehan nilai post-test minimal adalah 55,00 nilai maksimal adalah 80,00 perolehan nilai rata-rata adalah 67,83 . Dari data tersebut dengan menggunakan statistika untuk mendapatkan kelas interval diperoleh banyak kelas sejumlah 6 dengan interval 5.

Berdasarkan daftar distribusi frekuensi nilai post-test di atas dapat diketahui bahwa pada 
kelas kontrol, siswa paling banyak memperoleh nilai dengan rentang antara 65 hingga 69 , hal ini dapat dilihat dari total frekuensi relatif pada rentang tersebut adalah 30\% atau sejumlah 9 siswa. Sedangkan, berdasarkan frekuensi relatif dan absolut, nilai dengan rentang paling kecil, yakni antara 55 hingga 59 diperoleh 2 siswa atau sejumlah $6,67 \%$. Nilai varian dan simpangan baku yakti, 42,50 dan 6,51.

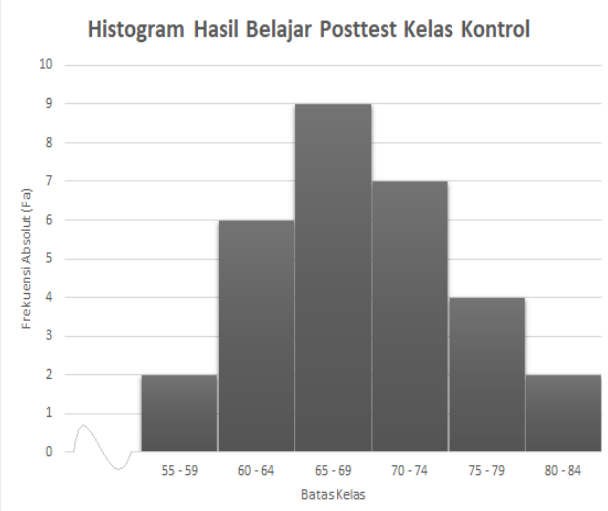

Gambar 1. Histogram Hasil Belajar Hasil Belajar Post-Test Instalasi Motor Listrik Kelas Kontrol

\section{Hasil Belajar Post-Test Instalasi Motor Listrik Kelas Eksperimen}

Jumlah sampel yang digunakan pada kelas eksperimen, yakni pembelajaran menggunakan media pembelajaran Trainer Control Motor adalah 30 siswa dengan perolehan nilai post test minimal adalah 70,00 nilai maksimal adalah 90,00 perolehan nilai rata-rata adalah 80,58. Dari data tersebut dengan menggunakan statistika untuk mendapatkan kelas interval diperoleh banyak kelas sejumlah 6 dengan interval 4.

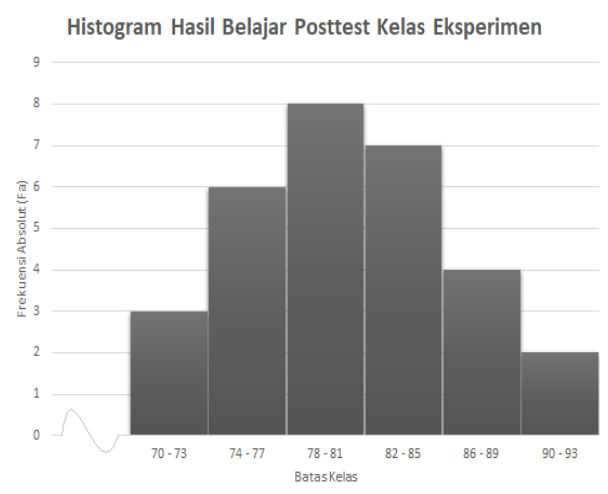

Gambar 2 Histogram Hasil Belajar Post-Test Instalasi Motor Listrik Kelas Eksperimen

Berdasarkan daftar distribusi frekuensi nilai post-test di atas dapat diketahui bahwa pada kelas eksperimen, siswa paling banyak memperoleh nilai dengan rentang antara 78 hingga 81, hal ini dapat dilihat dari total frekuensi relatif pada rentang tersebut adalah $26,67 \%$ atau sejumlah 8 siswa. Sedangkan, berdasarkan frekuensi relatif dan absolut, nilai dengan rentang paling kecil, yakni antara 70 hingga 73 yang diperoleh 3 siswa atau sejumlah $10 \%$. Nilai varian dan simpangan baku yakti, 30,02 dan 5,47.

\section{Hasil Pengujian Persyaratan Analisis Hasil Pengujian Normalitas}

Normalitas pada hasil post-test dilakukan dengan menggunakan uji lillifors dengan taraf signifikasi $\alpha=0,05$. Dari hasil perhitungan normalitas pada kelas kontrol diperoleh nilai $\mathrm{L}_{\text {hitung }}=0,0628$, sedangkan $\mathrm{L}_{\text {tabel }(0,05)}=0,161$. Jadi $\mathrm{L}_{\text {hitung }}<\mathrm{L}_{\text {tabel, }}$ yakni $0,062<0,161$, maka $\mathrm{H}_{\mathrm{o}}$ diterima. Dengan demikian dapat disimpulkan bahwa siswa yang tidak menggunakan media pembelajaran Trainer Control Motor berdistribusi normal.

Dari sampel siswa yang menggunakan Trainer Control Motor diperoleh hasil perhitungan nilai post-test $\mathrm{L}_{\text {hitung }}=0,137$, sedangkan $\mathrm{L}_{\text {tabel }(0,05)}=0,161$. Jadi $\mathrm{L}_{\text {hitung }}<\mathrm{L}_{\text {tabel }}$, maka $\mathrm{H}_{\mathrm{o}}$ diterima. Maka dari itu, disimpulkan data siswa yang menggunakan media pembelajaran Trainer Control Motor berdistribusi normal.

\section{Hasil Pengujian Homogenitas}

Pengujian homogenitas untuk hasil post-test dilakukan terhadap siswa yang menggunakan video pembelajaran dengan yang tidak menggunakan video pembelajaran dilakukan menggunakan uji Fisher dengan taraf signifikan 0,05. Dari hasil perhitungan didapatkan $F_{\text {hitung }}<$ $\mathrm{F}_{\text {tabel }}$ atau $1,41<4,02$. Artinya dari perhitungan ini dapat disimpulkan populasi kelas kontrol dan kelas eksperimen berasal dari variansi yang homogen.

\section{Uji Hipotesis}

Berdasarkan hasil perhitungan, untuk perhitungan uji $\mathrm{t}$ diperoleh nilai $\mathrm{t}_{\text {hitung }}=8,225$ sedangkan $\mathrm{t}_{\text {tabel }}=2,001$, untuk derajat kebebasan 58 dengan taraf signifikansi 5\%. Berdasarkan kriteria pengujian yang digunakan karena $t_{\text {hitung }}>t_{\text {tabel }}$, maka $\mathrm{H}_{\mathrm{o}}$ ditolak dan $\mathrm{H}_{\mathrm{i}}$ diterima yang artinya terdapat perbedaan hasil belajar instalasi motor listrik antara siswa yang menggunakan media pembelajaran berupa Trainer Control Motordengan siswa yang 
menggunakan tidak media pembelajaran. Berdasarkan hal tersebut, maka dapat disimpulkan bahwa terdapat pengaruh media pembelajaran terhadap hasil belajar instalasi motor listrik.

\section{KESIMPULAN DAN SARAN Kesimpulan}

Hasil penelitian yang telah dilakukan menunjukan bahwa pada post-test, hasil ratarata nilai kelas eksperimen mengungguli kelas kontrol. Pada hasil perhitungan nilai post-test kelompok eksperimen didapatkan rata-rata nilai sebesar 80,58, dengan nilai terendahnya sebesar 70,00 dan nilai tertingginya sebesar 90,00. Sedangkan dari perhitungan post-test kelompok kontrol didapatkan nilai rata-rata sebesar 67,83 dengan nilai terendahnya adalah 55,00 dan tertingginya adalah 80,00 . Hasil perhitungan hipotesis penelitian menunjukan thitung $>t_{t a b e l}$, yakni 8,225> 2,001. Berdasarkan data-data diatas, dapat disimpulkan bahwa terdapat pengaruh penggunaan media pembelajaran Trainer Control Motorterhadap hasil belajar instalasi motor listrik.

\section{Saran}

Berdasarkan Hasil penelitian yang telah dicapai, maka disarankan penggunaan media pembelajaranTrainer Control Motorsebagai media pembelajaran, dimanadalam penggunaannya siswa lebih paham dan mendapatkan wawasan secara langsung mengenai teori yang memerlukan pengaplikasian langsung sehingga dapat mempengaruhi hasil belajar siswa.

\section{DAFTAR PUSTAKA}

Anwar, I. (2010). Pengembangan Bahan Ajar. Bandung: Bahan Kuliah online. Direktori UPI.

Arsyad, A. (2008). Media Pembelajaran. Jakarta: PT. Rajagrafindo Persada.

Hamalik, O. (2003). Proses Belajar Mengajar. Jakarta: Bumi Aksara.

Haryati. (2014). Pengaruh Penggunaan Media Pembelajaran Terhadap Hasil Belajar Siswa Pada Mata Pelajaran IPS Terpadu Di SMP Negeri 12 Palu.

Hidayat, A., \& Machali, I. (2012). Pengelolaan Pendidikan. Yogyakarta: Kaukaba.
James W, B., Richard B, L., \& Fred F, H. (1977). AV instruction: Technology, Media, and Methods. New York: McGraw-Hill, Inc.

Kunandar. (2015). Penilaian Autentik; Penilaian Hail Belajar Peserta Didik Berdasarkan Kurikulum 2013. Jakarta: PT. Rajagrafindo Persada.

Munadi, Y. (2010). Media Pembelajaran; Sebuah Pendekatan Baru. Jakarta: Gaung Persada (GP) Press.

Musfiqon, H. (2012). Pengembangan Media dan Sumber Pembelajaran. Jakarta: PT. Prestasi Pustakaraya.

Nurcahyo, P. A. (2016). Pengaruh Penggunaan Media Pembelajaran Terhadap Hasil Belajar Siswa Mata Pelajaran Kelistrikan Mesin \& Konversi Energi di SMK N 2 Depok. Nurul, F. (2017). Pengaruh Media Pembelajaran Terhadap Hasil Belajar Instalasi Motor Listrik.

Rasimin, Subqi, I., Sapruto, H. E., \& Musyahadah, E. (2012). Media Pembelajaran Teori dan Aplikasi . Yogyakarta: PT Trus Media Publishing.

Santoso, T. (2015). Pengembangan Unit Modul Trainer Praktik Instalasi Listrik Industri.

Setiawan, A. L., \& Yuniarti, N. (2017). Pengembangan Media Pembelajaran Trainer KIT Sistem Pengendali Elektromagnetik.

Sudjana, N. (2001). Penelitian dan Penilaian Pendidikan. Bandung: Sinar Baru.

Sugiyono. (2011). Metode Penelitian dan Kuantitatif Kualitatif dan R\&D.Bandung: ALFABETA

Sukmadinata, N. S. (2011). Landasan Psikologi Proses Pendidikan. Bandung: PT. Remaja Rosdakarya.

Winkel. (2009). Psikologi Pengajaran. Yogyakarta: Media Abadi 